\author{
BOŻENA KICZOROWSKA, WIOLETTA SAMOLIŃSKA, RENATA KLEBANIUK, \\ EDYTA KOWALCZUK-VASILEV, IZABELA WÓJCIK
}

\title{
Pregnant women's attitudes towards organic food
}

\begin{abstract}
Introduction. Proper and healthy nutrition during pregnancy is one of the strongest external determinants of normal development of the foetus. Due to its health-enhancing properties, organic food is its desirable element. Therefore, the analysis of the consumer behaviour associated with organic food among pregnant women seems relevant, in particular given the small number of scientific reports addressing this problem.

Aim. The aim of the study was to analyse pregnant women's behaviour and attitudes towards organic food. The investigations included opinions of the entire group of respondents and was intended to show differences between individual groups of women classified in terms of having children already or not.

Material and methods. The survey involved 100 pregnant women living in Lublin and its surroundings, which were assigned into two survey groups: women already having children and those without children. An anonymous questionnaire designed as part of the study was the research tool. The questions were focused on indication of the motivations in the purchase and sources of information about organic food as well as consumer behaviour on the organic food market.

Results. A majority of pregnant women assessed their financial situation as satisfactory. The main motive behind buying organic food was their wish to take special care of their health during the pregnancy period and the need to take care of the family. The women were familiar with the concept of organic food. Commercials were the frequent source of information among women expecting the first child and the Internet was the main source of information for those already having children. As specified by the pregnant women, health benefits, naturalness and the absence of chemical contamination are the characteristic features of organic food. Most of the respondents declared an intention to feed their children with organic food to minimise the exposure to chemical contamination.

Conclusions. There were differences in the use of sources of information about organic food or the importance of individual determinants of their purchase by the pregnant women. This knowledge can be used on the organic food market to develop marketing solutions, which will be useful in satisfying the needs of this group of consumers more effectively.
\end{abstract}

Keywords: organic food, pregnant women, children, healthy nutrition.

DOI: $10.1515 /$ pjph-2017-0034

\section{INTRODUCTION}

Organic farming and organic food are associated with such attributes as naturalness and attainable food safety [1,2]. This aspect is particularly important in the case of consumers that are at the highest risk of exposure to the negative impact of chemical contamination, e.g. pregnant women and children [3-5]. The diet of a pregnant woman should be based on food products characterised by high nutritional and health-enhancing quality. However, the available literature provides little information on the actual relevance of this type of food in the diet of pregnant women as well as their consumer behaviours and motivations in the purchase of organic food.
AIM
The aim of the study was to analyse the behaviour and atti- tudes of pregnant women towards organic food. The research was based on opinions expressed by the surveyed respondent

group and differences between the groups of women already having children and those expecting the first child.

\section{MATERIAL AND METHODS}

The empirical study was conducted using the PAPI (Paper and Pencil Interviewing) method. An anonymous questionnaire was used as a research tool. The respondent inclusion criteria were consent to participate in the survey and pregnancy. The sample consisted of 100 women aged from 18 to 44 living in Lublin and its surroundings. They were assigned to two survey groups distinguished in terms of having children. The first group were pregnant women with no other children, and the second group were pregnant women who already had at least one child.

The questionnaire was constructed in accordance with the rules for survey data collection [6]. There were questions about the sources of information on organic food, motivations in the purchase of such food, and organic products for which the respondents would be willing to pay a higher price than 
for a conventional product. Additionally, the respondents answered questions about the frequency of organic food purchase and were asked to define the characteristic features of organic products. They were also asked whether they would decide to feed their offspring with organic food in the future.

The results were statistically analysed using the Statistica version 13 computer program (Dell Inc. 2016). To determine statistically significant correlations between the answers and the differentiating factor (having children), the Pearson's nonparametric $\chi^{2}$ test was used (Yates correction was applied in justified cases). The value of $\alpha=0.05$ was assumed as the level of significance (significant differences at $\mathrm{p}<0.05$ ). Pearson's $\mathrm{C}$ contingency ratio was calculated to determine the strength of the correlations [7]. The results are presented as means, medians $\left(Q_{2}\right)$, and percentages of answers in the individual groups and for the total number of the surveyed respondents.

\section{RESULTS}

The average age of the respondents was 24.38 years $\left(Q_{2}=23.5\right.$ years $)$ in group $I$, and 30.29 years $\left(Q_{2}=30.0\right.$ years $)$ in group II. The women in the first group had no other children. In group II, $66 \%$ of the pregnant women had one child, $24 \%$ had two children, and $10 \%$ had three children. Approximately $40 \%$ of the respondents had higher education. Secondary education was declared by a similar percent of the women from group I and by approximately $30 \%$ in group II. A similar percentage, i.e. approximately $30 \%$, of the respondents from this group had basic vocational education. In both groups, occupationally active pregnant women accounted for the highest percentage. In group II, they accounted for $62 \%$, whereas only $36 \%$ of the pregnant women with no other children had a job. In this group, over $50 \%$ were professionally inactive $(26 \%)$ or studied (ca. $26 \%)$. A vast majority of the group-I respondents estimated their material status as good (67\%), while this answer was chosen less frequently by the respondents who already had children (41\%). The women in group II declared a moderate material status (40\%), whereas this answer was chosen by a two-fold lower number of the respondents from group I. Over $67 \%$ of the pregnant women in group I and $60 \%$ of the respondents in group II lived in the city.
More than half of the surveyed women knew the concept of organic food (Table 1). Approximately $40 \%$ of the respondents from each group only heard about organic food and had insufficient knowledge about it. Only 5\% of the women surveyed did not know what organic food was $(\mathrm{p}=0.856)$. The Internet $(48 \%)$ and commercials $(43 \%)$ were indicated as the most popular sources of information. The respondents expecting the first child most frequently indicated commercials as the source of information, in contrast to the women with children $(p=0.043)$. However, the strength of the correlation between having children and the choice of this source of information was weak $(C=0.198)$. The television (36\%) and the press $(35 \%)$ as well as study courses (24\%) were a frequent source of knowledge about organic food indicated by all the respondents. The lowest amount of information was provided to the respondents by a doctor/dietitian $(6 \%)$.

The pregnant women most often declared varied frequency of buying organic food (63\%) or their own production of organic food $(11 \%)$. Every fourth respondent did not buy organic food (Figure 1). Approximately $27 \%$ of the pregnant women bought organic food several times or once a month, $22 \%$ of the respondents bought this type of food several times a year, and $14 \%$ declared buying organic food every day or several times a week. The differences in the frequency of organic food purchase between these two groups of pregnant women were not significant $\left(\chi^{2}=9.41 ; p=0.224\right)$.

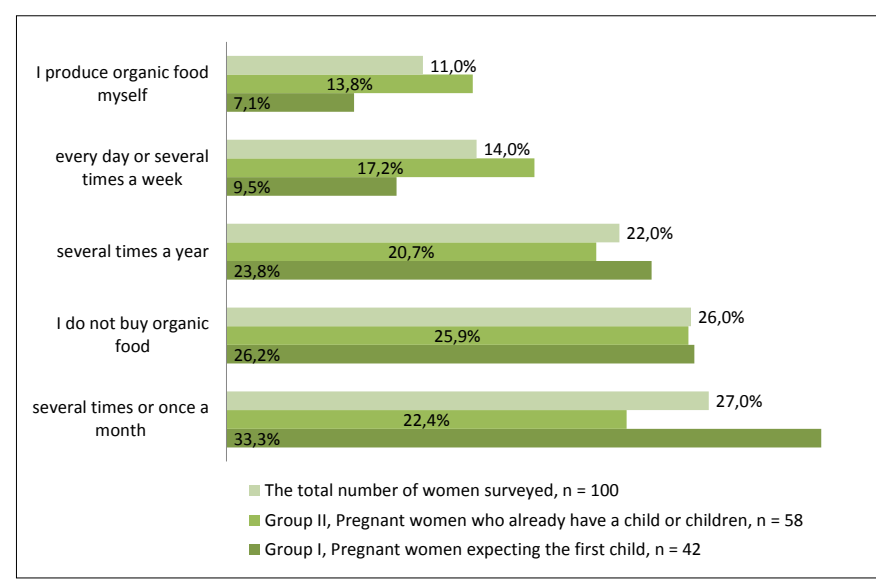

FIGURE 1. Frequency of organic food purchase by pregnant women.

TABLE 1. Knowledge of the concept of organic food and sources of information indicated by the respondents.

\begin{tabular}{|c|c|c|c|c|c|}
\hline Variables & $\begin{array}{c}\text { Group I, Pregnant } \\
\text { women expecting } \\
\text { the first child, } n=42\end{array}$ & $\begin{array}{c}\text { Group II, Pregnant } \\
\text { women having one child } \\
\text { or children, } n=58\end{array}$ & $\begin{array}{c}\text { Total number } \\
\text { of respondents, } \\
n=100\end{array}$ & $\chi 2$ value & p value \\
\hline \multicolumn{6}{|l|}{ Knowledge of the concept of organic food } \\
\hline yes, I definitely know what organic food is & 50.0 & 55.2 & 53.0 & \multirow{3}{*}{0.312} & \multirow{3}{*}{0.856} \\
\hline I have heard about organic food, but I do not know a lot about it & 45.2 & 39.7 & 42.0 & & \\
\hline I don't know & 4.8 & 5.2 & 5.0 & & \\
\hline \multicolumn{6}{|l|}{ Sources of information about organic food } \\
\hline Internet & 50.0 & 46.6 & 48.0 & 0.120 & 0.733 \\
\hline commercials & 54.8 & 34.5 & 43.0 & 4.090 & 0.043 \\
\hline television & 26.2 & 43.1 & 36.0 & 3.020 & 0.082 \\
\hline press & 31.0 & 37.9 & 35.0 & 0.520 & 0.470 \\
\hline studies & 31.0 & 19.0 & 24.0 & 1.920 & 0.166 \\
\hline acquaintances & 9.5 & 20.7 & 16.0 & 2.260 & 0.133 \\
\hline shop & 9.5 & 17.2 & 14.0 & 1.210 & 0.272 \\
\hline family & 9.5 & 13.8 & 12.0 & 0.420 & 0.517 \\
\hline events promoting organic food & 9.5 & 10.3 & 10.0 & 0.020 & 0.839 \\
\hline doctor/dietitian & 2.4 & 8.6 & 6.0 & 1.680 & 0.195 \\
\hline
\end{tabular}


As defined by a majority of the respondents, organic food is primarily healthy (73\%) and natural (60\%) (Table 2). Approximately $40 \%$ of the women thought that the food was free from chemical contaminants (40\%) and expensive (36\%). Only 5\% of the women indicated low attractiveness of the appearance of organic food, and $6 \%$ of women pointed a much higher nutritional value of such food than that of conventional food. There were no statistical differences in the responses between both respondent groups $(p<0.05)$. The main reason for the purchase of organic products expressed by the respondents was the need to take special care of their health during the pregnancy time $(47 \%)$. The need to look after the family was indicated by over $40 \%$ of the women. This answer was chosen more frequently in group II than in group I ( $50 \%$ vs $28.6 \%$; $=0.032)$. The strength of the correlation between having children and this choice was weak $(C=0.210)$. An important purchase motivation was the care for the natural environment, as $15 \%$ of the respondents chose this answer. Some women consumed organic products following the fashion for a healthy lifestyle (8\%) and due to the palatability of organic food $(11 \%)$. The lowest percentage of the pregnant women mentioned doctor's recommendations as the motivation (4\%). Organic products for which the respondents would be ready to pay a higher price included meat (63\%), food for children (34\%), milk (30\%), fruit $(26 \%)$, and vegetables (24\%). Every tenth pregnant women declared readiness to pay a higher price of organic juice. Only this answer statistically differentiated both respondent groups. Pregnant women expecting the first child chose this product and declared that they would accept its higher price, in contrast to the women who had other children ( $19 \%$ vs $5.2 \%$; $=0.029)$. However, the strength of the correlation between the differentiating factor and the choice of this answer was weak $(\mathrm{C}=0.214)$.

Over $60 \%$ of the respondents declared that the future nutrition of their children will be based on organic food due to its health safety. Every third woman had no opinion on the subject, and only $4 \%$ declared that they would not make this decision (Figure 2). There were no statistically significant differences in the responses regarding the future use of organic products in the child nutrition between the respondent groups $\left(\chi^{2}=0.836 ; \mathrm{p}=0.658\right)$.

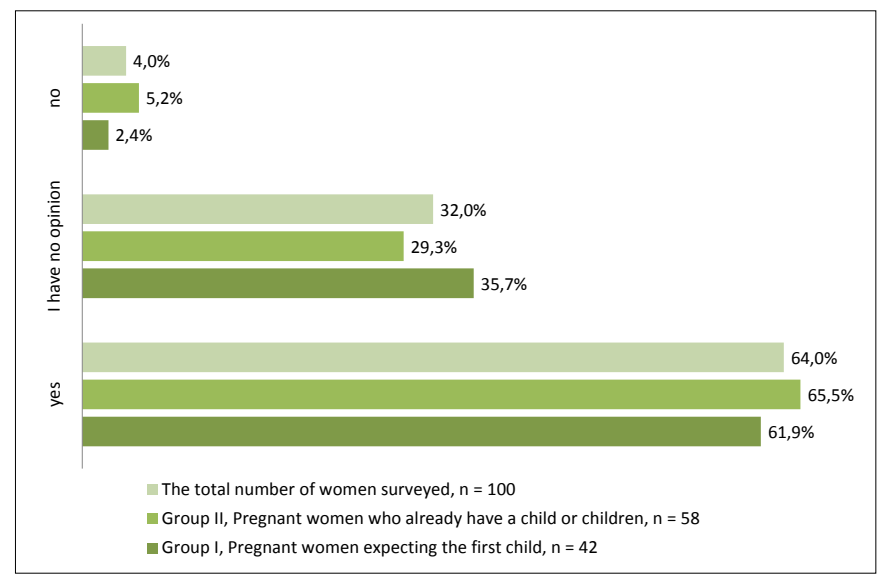

FIGURE 2. Decision on the use of organic products in child nutrition.

TABLE 2. Characteristics of organic food and motivation for its purchase specified by the respondents and organic products for which the respondents would be willing to pay a higher price than for their conventional counterparts.

\begin{tabular}{|c|c|c|c|c|c|}
\hline & $\begin{array}{c}\text { Group I, Pregnant } \\
\text { women expecting } \\
\text { the first child, } n=42\end{array}$ & $\begin{array}{c}\text { Group II, Pregnant } \\
\text { women having one child } \\
\text { or children, } n=58\end{array}$ & $\begin{array}{c}\begin{array}{c}\text { Total number } \\
\text { of respondents, } \\
\mathbf{n}=100\end{array}\end{array}$ & $\chi^{2}$ value & p value \\
\hline \multicolumn{6}{|l|}{ Characteristics of organic food } \\
\hline healthy & 66.7 & 77.6 & 73.0 & 1.47 & 0,225 \\
\hline natural & 54.8 & 63.8 & 60.0 & 0.83 & 0,363 \\
\hline free from chemical contaminants & 33.3 & 44.8 & 40.0 & 1.34 & 0,247 \\
\hline expensive & 40.5 & 32.8 & 36.0 & 0.63 & 0,427 \\
\hline low processing degree & 33.3 & 17.2 & 24.0 & 3.46 & 0,063 \\
\hline high palatability & 11.9 & 10.3 & 11.0 & 0.06 & 0,806 \\
\hline higher nutritional value than that of conventional food & 9.5 & 3.5 & 6.0 & 1.59 & 0,207 \\
\hline low attractiveness of appearance & 7.1 & 3.5 & 5.0 & 0.70 & 0,403 \\
\hline \multicolumn{6}{|l|}{ Motivation in purchase of organic food } \\
\hline $\begin{array}{l}\text { need to take care of health in the current physiological } \\
\text { condition (pregnancy) }\end{array}$ & 57.1 & 39.7 & 47.0 & 2.99 & 0,084 \\
\hline need to take care of the family & 28.6 & 50.0 & 41.0 & 4.62 & 0,032 \\
\hline care for the natural environment & 16.7 & 13.8 & 15.0 & 0.16 & 0,691 \\
\hline palatability & 9.5 & 12.1 & 11.0 & 0.16 & 0,688 \\
\hline fashion for a healthy lifestyle & 7.1 & 8.6 & 8.0 & 0.07 & 0,788 \\
\hline doctor's recommendations & 7.1 & 1.7 & 4.0 & 1.86 & 0,172 \\
\hline \multicolumn{6}{|c|}{ Groups of organic products for which pregnant women would be willing to pay a higher price } \\
\hline meat & 57.1 & 67.2 & 63.0 & 1.07 & 0,302 \\
\hline food for children & 33.3 & 34.5 & 34.0 & 0.01 & 0,905 \\
\hline milk & 33.3 & 27.6 & 30.0 & 0.38 & 0,536 \\
\hline fruit & 26.2 & 25.9 & 26.0 & 0.01 & 0,971 \\
\hline vegetables & 26.2 & 22.4 & 24.0 & 0.19 & 0,663 \\
\hline cereals & 16.7 & 20.7 & 19.0 & 0.26 & 0,613 \\
\hline eggs & 14.3 & 20.7 & 18.0 & 0.68 & 0,411 \\
\hline fruit preserves & 16.7 & 10.3 & 13.0 & 0.86 & 0,354 \\
\hline honey & 14.3 & 10.3 & 12.0 & 0.36 & 0,549 \\
\hline juice & 19.1 & 5.2 & 11.0 & 4.79 & 0,029 \\
\hline vegetable preserves & 14.3 & 5.2 & 9.0 & 2.47 & 0,116 \\
\hline
\end{tabular}




\section{DISCUSSION}

As a result of the decreasing consumer confidence in conventional food and the increasing consumer awareness of the importance of rational nutrition determining good health status, the modern market is continuously searching for organic food. The consumer motivation in the purchase of organic food is based on the perception thereof as healthy and safe products. An equally important argument is the absence of chemical contaminants and the production methods based on natural manufacturing processes in harmony with the natural environment $[1,2,8]$. This is in line with the results obtained in this study, as the characteristics ascribed by the pregnant women to organic food included its heathy, natural, and chemical contaminant-free nature. The purchase of organic food by the respondents was mainly prompted by the need to take special care of their health during the pregnancy period and the family. The literature provides reports on the health-enhancing effect of organic food on pregnant women and their children associated with a lower risk of preeclampsia [5] as well as atopic eczema and allergies in children [3].

Half of the pregnant women surveyed in this study were familiar with the concept of organic food, and $40 \%$ of the respondents have heard about such products but their knowledge was insufficient. They found information about organic food mainly in the media, which are a widely available, rich, simple, and convenient source of valuable information for the consumer. Similar results were also reported in previous studies focused on the opinions of pre-school children's mothers about this type of food products [9].

As reported in other studies $[1,9,10]$, the pregnant women purchased organic food infrequently, i.e. several times or once a month or sporadically (several times a year). Only $14 \%$ of the respondents declared that they bought it every day or several times a week. However, it should be noted that $11 \%$ of the pregnant women had access to self-produced organic food. In investigations conducted by Torjusen et al. [4] on pregnant women in Norway, frequent organic consumption was declared by only $9.1 \%$ of women. As demonstrated by ŁuczkaBakuła [11], consumers of organic food can be divided into three groups of regular, periodic, and occasional buyers.

The period of pregnancy is a very important time for both the mother and her child. Nutrition of a pregnant woman is one of the most potent external determinants of normal development of the foetus. Inadequate levels of nutrients in the mother's organism or the presence of chemical contaminants may predispose the child to chronic diseases in adulthood. Therefore, it is essential to follow the principles of a healthy and rational diet during pregnancy with organic food as a desirable element of the diet [12]. In the present study, the pregnant women were ready to accept higher expenses related to the purchase of organic food. Most often, they indicated such products as meat (63\%) or food for children $(34 \%)$. The analysis of the readiness to introduce organic food to child nutrition due to its health safety has demonstrated a positive attitude in more than $60 \%$ of the respondents. The previous survey of opinions expressed by pre-school children's mothers [9] showed similar readiness to accept the higher costs of such organic food as vegetables (59\%), fruit (54\%), cured meat $(43 \%)$, or eggs, bread, meat, and juice (approx. 37\%). There are many reports in the available literature emphasising a strong correlation between mother's nutritional awareness and knowledge and the choice of food for their children. This indicates an important role played by mothers in maintenance of good health in their children and development of appropriate nutritional behaviours $[13,14]$.

\section{CONCLUSIONS}

1. A majority of the respondents declared buying organic food infrequently.

2. The respondents were familiar with the concept of organic food. The frequent sources of information about these products were commercials, as indicated by the women expecting the first child, and the Internet in the case of the respondents with other children.

3. The main reasons for consumption of organic food were the need to take special care of health during the pregnancy time and the need to look after the family. However, the respondents with children indicated the need to look after the family as the major motivation.

4. The pregnant women declared their readiness to accept higher costs of selected organic food products.

5. Most of the respondents declared readiness to introduce organic food to child nutrition due to its health-enhancing quality.

6. Differences were noted in the use of the sources of information about organic food or the importance of individual determinants of their purchase by the pregnant women. This knowledge can be used on the organic food market to develop marketing solutions that will help fulfil the needs of this group of consumers more effectively.

\section{REFERENCES}

1. Hermaniuk T. Organic food market in Poland - main characteristics and factors of development. Sci Ann Econ Bus. 2016;63(1):135-47.

2. Miśniakiewicz M, Suwała G. Żywność ekologiczna w świadomości Polaków. Zesz Nauk. AE Krak. 2006;705:57-75.

3. Kummeling I, Thijs C, Huber M, et al. Consumption of organic foods and risk of atopic disease during the first 2 years of life in the Netherlands. Br J Nutr. 2008;99(3):598-605.

4. Torjusen H, Lieblein G, Næs T, et al. Food patterns and dietary quality associated with organic food consumption during pregnancy; data from a large cohort of pregnant women in Norway. BMC Public Health. 2012;12(1):612. doi.org/10.1186/1471-2458-12-612.

5. Torjusen H, Brantsaeter AL, Haugen M, et al. Reduced risk of pre-eclampsia with organic vegetable consumption: results from the prospective Norwegian Mother and Child Cohort Study. BMJ Open. 2014;4(9). doi:10.1136/bmjopen-2014-006143.

6. Stupnicki R. Analiza i prezentacja danych ankietowych. Warszawa: Wyd. Akademia Wychowania Fizycznego; 2003.

7. Stanisz A. Przystępny kurs statystyki na przykładach $\mathrm{z}$ medycyny z wykorzystaniem programu Statistica, t. I, wyd. II. Kraków: Statsoft; 2006.

8. Samolińska W, Kiczorowska B. Żywność ekologiczna w opinii internautów - doniesienia wstępne. Probl Hig Epidemiol. 2013;94(3):630-4.

9. Samolińska W, Kiczorowska B. Marzec A, et al. Żywność ekologiczna w opinii matek dzieci w wieku przedszkolnym w Lublinie. Probl Hig Epidemiol. 2017;98(3):266-70.

10. Kowalczuk-Vasilev E, Klebaniuk R, Gronowicz K. Żywność ekologiczna w opinii studentów różnych lat studiów uczelni lubelskich. Probl Hig Epidemiol. 2011;92(4):960-4.

11. Łuczka-Bakuła W. Rynek żywności ekologicznej. Wyznaczniki i uwarunkowania rozwoju. Warszawa: Polskie Wydawnictwo Ekonomiczne; 2007.

12. Przybyłowicz K, Kalinowska K. Żywienie kobiet w ciąży a stan urodzeniowy noworodków wyrażony indeksem Ponderala. Probl Hig Epidemiol. 2011;92(3):508-11.

13. Osera T, Tsutie S, Kobayashi M, et al. The effect of mothers' and fathers' food preferences on children's preferences with their attitude. European J Nutr Food Saf. 2016;6(3):93-100. 
14. Vereecken C, Maes L. Young children's dietary habits and associations with the mothers' nutritional knowledge and attitudes. Appetite. 2010;54(1):44-51.

Corresponding author

Dr Wioletta Samolińska

Department of Bromatology and Nutrition Physiology

Institute of Animal Nutrition and Bromatology

University of Life Sciences

13 Akademicka St., 20-950 Lublin, Poland

E-mail: wioletta.samolinska@up.lublin.pl

tel. (+48 81) 4456914 